\title{
THE EFFECTS OF HIGH DOSES OF NANDROLONE DECANOATE ON CARDIAC MUSCLE TISSUE
}

Jasmina Sretenovic ${ }^{1}$, Vladimir Zivkovic $^{1}$, Ivan Srejovic ${ }^{1}$ and Zoran Milosavljevic ${ }^{2}$

${ }^{1}$ Department of Physiology, Faculty of Medical Science, University of Kragujevac, Kragujevac, Serbia

${ }^{2}$ Department of Histology and embryology, Faculty of Medical Science, University of Kragujevac, Kragujevac, Serbia

\author{
EFEITI VISOKIH DOZA NANDROLON DEKANOATA \\ NA SRČANO MIŠIĆNO TKIVO \\ Jasmina Sretenović ${ }^{1}$, Vladimir Živković ${ }^{1}$, Ivan Srejović ${ }^{1}$ i Zoran Milosavljević ${ }^{2}$ \\ ${ }^{1}$ Katedra za fiziologiju, Fakultet Medicinskih Nauka, Universitet u Kragujevcu, Kragujevac, Srbija \\ ${ }^{2}$ Katedra za Histologiju i embriologiju, Fakultet Medicinskih Nauka, Univerzitet u Kragujevcu, Kragujevac, Srbija
}

Received / Primljen: 19. 02. 2016.

Accepted / Prihvaćen: 29. 02. 2016.

\begin{abstract}
In recent decades, steroid abuse has become very popular and widespread among professional and recreational athletes. The aim of this study was to examine the chronic effects of training combined with high doses of nandrolone decanoate on cardiac muscle tissue. The study included 32 Wistar albino rats divided into 4 groups: control (T-N-), steroid ( $(T-N+)$, exercisetraining $(T+N-)$ and exercise plus steroid $(T+N+)$ groups. The $T+N$ - and $T+N+$ group swam for 4 weeks, 1 hour per day, 5 days per week. The $N+$ (nandrolone positive groups) received nandrolone decanoate $(20 \mathrm{mg} / \mathrm{kg}$ ) once per week, subcutaneously. After 4 weeks of training, the rats were sacrificed. Heart biopsy specimens were routinely fixed and embedded in paraffin. Fivemicrometre thick sections were stained with haematoxylin and eosin (H/E) and Masson-Trichrome dyes. Captured microscopic images were processed by special software for image analysis to quantify results. Our results showed that the combination of nandrolone and training causes left ventricular wall thickening of $30 \%$. Average cardiac muscle cell longitudinal diameter was increased by $6 \%$ in the $T-N+$ group, by $16 \%$ in the $T+N-$ group and by $25 \%$ in the $T+N+$ group. The cross sectional muscle cell area was increased in the $T+N+$ group by $33 \%$. Heart collagen content was increased in the nandrolone group compared to the control group by $261 \%$. Collagen content was decreased in the $T+N+$ group by $34 \%$. High doses of AAS induced left ventricle hypertrophy and excessive heart collagen deposition.
\end{abstract}

Keywords: nandrolone decanoate, high doses, exercise, heart muscle

\section{SAŽETAK}

Poslednjih nekoliko decenija, zloupotreba AAS je postala veoma popularna i siroko rasprostranjena među rekreativnim i profesionalnim sportistima. Cilj istrazivanja je da pokaže hronične efekte treninga u kombinaciji sa visokim dozama nandrolon dekanoata na srčano mišićno tkivo. U studiju je ukljceno 32 mužjaka pacova, Wistar albino soja, podeljenih u 4 grupe: kontrola (T-N-), grupa na steroidima (T-N+), grupa koja trenira $(T+N-)$ i grupa koja trenira i prima steroide $(T+N+)$. Grupe $T+N-i T+N+$, plivale su 4 nedelje, $1 \mathrm{~h}$ dnevno, 5 dana u nedelji. Grupe koje primaju steroide (N+), dobijale su jednom nedeljno nandolon u dozi od $20 \mathrm{mg} / \mathrm{kg}$, subkutano. Nakon četvoronedeljnog treninga životinje su žr tvovane. Kompletna srca su rutinski fiksirana u ukalupljena u parafinske blokove. Preseci debljine $5 \mu \mathrm{m}$ bojeni su H/E $i$ Mason Trihrom tehnikom. Mikrofotografije dobijenih preparata su obradivanje specijalizovanim softverom za analizu slike u cilju kvantifikacije rezultata. Naši rezultati su pokazali da kombinacija treninga i nandrolona izaziva zadebljanje zida leve komore za 30\%. Srednji dijametar duznog preseka srčanog mišića se povećao za 6\% u T-N+ grupi, za 16\% u $T+N-i$ za $25 \%$ u $T+N+$ grupi. Poprečni presek je povećani za 33\% u $T+N+$ grupi. Depoziti kolagena u srcu bili su povecani u grupi $T-N+z a$ 261\% u poredenju sa kontrolnom grupom. Depoziti kolagena bili su sniženi u $T+N+$ grupi za $34 \%$. Visoke doze AAS izazivaju hipertrofiju zida leve komore i prekomerno deponovanje kolagena.

Ključne reči: Nandrolon, visoke doze, trening, srčani mišić. 


\section{INTRODUCTION}

Anabolic androgenic steroids (AAS), synthetic derivatives of testosterone, were created as an attempt to synthesize a testosterone-like steroid that would have strong anabolic effects (1). Because of these anabolic effects, AAS became very popular among professional and recreational athletes, even though they were banned in many organized sports $(2,3)$. The hormone is most frequently used among weightlifters, bodybuilders, swimmers and cyclists to improve their physical performance (4), strength and muscle mass (5). However, these individuals may take doses of up to 100 time higher doses than the therapeutic range, which leads to severe adverse effects on many organ systems (6).

Nandrolone is a derivate of 19-nortestosterone and is most often administered in the form of depot preparations. Today, it is the one of the most popular AAS among athletes. It has a stronger anabolic effect than testosterone, but with long-term usage (7), severe adverse effects such as structural and functional alterations of the liver and even hepatocellular adenoma can be detected (8). Furthermore, chronic abuse of AAS can lead to pathological left ventricular hypertrophy via androgenic receptors (9) located in the cytoplasmic compartment of the cardiac muscle cells $(10,11)$, as well as abnormalities of impulse conduction and contractility $(12,13)$. Studies have shown that abuse of AAS can induce hypertrophy of the left ventricle with disproportionate accumulation of extracellular collagen and interstitial fibrosis (14-17). Previous reports have further shown that chronic administration of supraphysiological doses of AAS can lead to increased interventricular septum thickness, dilated cardiomyopathy, arrhythmia, heart failure and sudden cardiac death $(9,14,18)$. On the other hand, exercise and endurance training are known to induce significant changes in the morphology of the heart, including increased left ventricular chamber size, wall thickness and increased mass of the heart, known as an "athlete's heart" (19). This is a balanced and reversible physiological modification that is followed by necessary neovascularization because muscle hypertrophy occurs as a result of the adaptation of the cardiac muscle to increased physical activity (20).

A review of available literature showed that majority of the studies aimed at revealing the effects of AAS on cardiac muscle tissue (with or without training) were designed to investigate the influence of supraphysiological doses (up to $10 \mathrm{mg} / \mathrm{kg}$ ) of steroids on the heart $(5,14$, 17, 21). However, considering that some individuals, in attempt to rapidly increase their muscle mass and performance, are taking up to $20 \mathrm{mg} / \mathrm{kg}$ of AAS, we wanted to gain a better understanding of the effects on cardiac muscle tissue morphology of high-dose nandrolone decanoate administered either alone or in combination with training over a short-term interval.

\section{MATERIAL AND METHODS}

\section{Experimental animals}

This study included 32 male Wistar albino rats (10 weeks old, weighing 220-280 g). Rats were housed in collective cages (eight rats per cage). Food and water were provided ad libitum. The room temperature was kept at $25 \pm 1^{\circ} \mathrm{C}$ with 12 -h alternating light and dark cycles. The rats were randomly divided into four groups: T-N- (sedentary rats with no administration of nandrolone decanoate or exercise training; control group), $\mathrm{T}-\mathrm{N}+$ (sedentary rats with weekly administration of nandrolone decanoate (depot preparation, $20 \mathrm{mg} / \mathrm{kg}$ s.c. during a period of 4 weeks), $\mathrm{T}+\mathrm{N}$ - (exercising rats (swimming $1 \mathrm{~h} /$ day) with no administration of nandrolone decanoate) and $\mathrm{T}+\mathrm{N}+(\mathrm{ex}-$ ercising rats (swimming training $1 \mathrm{~h} /$ day) with weekly administration of nandrolone decanoate depot preparation $20 \mathrm{mg} / \mathrm{kg}$ s.c. during a period of 4 weeks). Over the course of 4 weeks, the steroid and exercise-training plus steroid group received nandrolone decanoate (DECA DURABOLIN $^{*}$, Organon, Holland) administered by subcutaneous injection once per week in doses of $20 \mathrm{mg} / \mathrm{kg}$. The initial and final body weights (BW) and heart weight (HW) were measured. During the 4 weeks, rats were swimming in a pool of $120 \times 80 \times 50-\mathrm{cm}$ length/depth/width) for 1 hour per day, 5 days per week. The swimming was performed every exercise day starting at 9 a.m. The water temperature was $37^{\circ} \mathrm{C}$. After the experimental period, the rats were sacrificed. After short-term anaesthesia (ketamine $100 \mathrm{mg} /$ $\mathrm{kg}$ and xilazid $10 \mathrm{mg} / \mathrm{kg}$ ), the animals were premedicated with heparin as an anticoagulant and were sacrificed by cervical dislocation (Schedule 1 of the Animals/Scientific Procedures, Act 1986 UK), and their hearts were surgically removed for histological examination. This protocol was approved by the Ethics committee, Faculty of Medical Science, University of Kragujevac.

\section{Histological and image analysis}

The isolated rat hearts were halved so that the left and right ventricular walls were fully exposed. The organs were fixed in $4 \%$ formalin, routinely processed and embedded in paraffin. Sections, $5 \mu \mathrm{m}$ thin, were stained with $\mathrm{H} / \mathrm{E}$, for the visualization of tissue structures, and with MassonTrichrome dye for collagen detection and quantification. Images of tissue sections were captured with a digital camera attached to the Olympus BX51 microscope. Morphometric analysis was performed by calibrated Axiovision software (Zeiss, USA), as well as with Image Pro-Plus (Media Cybernetics, USA). All measurements were made in triplicate and average values were considered exact. From each half of the heart, 100 serial tissue sections were made. Odd sections were stained with $\mathrm{H} / \mathrm{E}$, and even ones were stained with Masson-Trichrome. Cross-sectional area, longitudinal-section diameter measurement of the cardiac muscle cells and collagen segmentation were performed 
Table 1. Body and heart weight measurements presented as the mean \pm SD

\begin{tabular}{|c|c|c|c|c|}
\hline & $\begin{array}{c}\text { Initial body } \\
\text { weight } \\
(\mathbf{g})\end{array}$ & $\begin{array}{c}\text { Final body } \\
\text { weight } \\
(\mathbf{g})\end{array}$ & $\begin{array}{c}\text { Heart } \\
\text { weight } \\
(\mathbf{g})\end{array}$ & $\begin{array}{c}\text { BW to HW } \\
\text { ratio }\end{array}$ \\
\hline $\mathrm{T}-\mathrm{N}-$ & $252 \pm 22.57$ & $438 \pm 35.04$ & $1.170 \pm 0.05$ & $374: 1$ \\
\hline $\mathrm{T}-\mathrm{N}+$ & $248 \pm 37.04$ & $401 \pm 23.12$ & $1.132 \pm 0.03$ & $354: 1$ \\
\hline $\mathrm{T}+\mathrm{N}-$ & $258 \pm 29.54$ & $406 \pm 30.55$ & $1.203 \pm 0.04$ & $337: 1$ \\
\hline $\mathrm{T}+\mathrm{N}+$ & $270 \pm 46.77$ & $416 \pm 49.44$ & $1.334 \pm 0.09$ & $312: 1$ \\
\hline
\end{tabular}

on 10 tissue sections for each specimen. Collagen quantification and image segmentation was done by two independent researchers, and mean values were considered exact.

\section{Statistical Analysis}

The ANOVA test was used for statistical comparison of data. $P$ values $p<0.05$ were considered statistically significant. All statistical calculations were made with the SPSS computer program, version 22.0 (SPSS Inc., Chicago, IL, USA). Data are presented as the means \pm standard deviations (SD).

\section{RESULTS}

\section{Body weight (BW) and heart weight (HW) measurement}

After the four-week experimental period, we found an increase in body weight compared to initial weight in all groups. The largest increase in body weight in the control group was $73 \%$, versus $55 \%$ in the $\mathrm{T}-\mathrm{N}+$ group, $57 \%$ in the $\mathrm{T}+\mathrm{N}$ - group and $54 \%$ in $\mathrm{T}+\mathrm{N}+$ group (Table 1 ). When $\mathrm{BW}$ to $\mathrm{HW}$ ratio was calculated at the end of the experiment, results showed that the lowest $\mathrm{BW} / \mathrm{HW}$ values occurred in groups where animals were exposed to training (with or without nandrolone administration), suggesting that training rather than nandrolone was the most influential factor (Table 1).

\section{Heart morphometry}

During the experiment, morphometry analysis was performed to estimate the effects of training and/or nandrolone administration on left ventricular wall thickness, heart muscle cell size and collagen content in the connective tissue of the heart.
Our findings showed that both nandrolone and exercise affected the left ventricular wall. Increased thickness was observed in all experimental groups, and the percentage of thickening ranged from $6 \%$ (only nandrolone administration) to almost 30\% (nandrolone and training together) compared to the control group (Table 2). Exercise only also led to a greater degree of wall thickening (16\%) than that induced by nandrolone administration alone (Fig 1A). Low-magnification overview of the left ventricular wall revealed that the thickening almost exclusively involved myocardium and did not significantly affect the other layers of the heart. Considering that the myocardium is mostly composed of contractile heart muscle cells, our results, unsurprisingly, showed a marked change in their diameter. Both longitudinal section diameter (LD) and cross-section area (CSA) were increased in all experimental groups compared to the control group. The group receiving nandrolone administration only revealed increases of $6 \%$ in LD and $13 \%$ in CSA, whereas the group receiving nandrolone and training together revealed increases of $25 \%$ and $33 \%$ (LD and CSA, respectively) compared to the control group (Table 1). Training alone induced increases in the size of heart muscle cells of 21\% (LD) and 23\% (CSA) (Fig 1b and 1c). There was a similar tendency in the results of left ventricular thickening, with average values positioned just between those of the $\mathrm{T}-\mathrm{N}+$ group and $\mathrm{T}+\mathrm{N}+$ group.

\section{Collagen content}

Results related to the collagen content of heart connective tissue showed that the strongest deposition was observed in the hearts of the animals that were exposed to nandrolone administration without training (261\% increase related to the control group). On the contrary, training alone and training combined with nandrolone administration caused a decrease in heart collagen content compared to the control group ( $45 \%$ for the $\mathrm{T}+\mathrm{N}$ - group and $34 \%$ for the $\mathrm{T}+\mathrm{N}+$ group) (Table 2) (Fig. 1d). It was therefore clear that training alone induced the most significant decrease in collagen content of the heart.

\section{DISCUSSION}

Anabolic androgenic steroids (AAS), although banned in sports, are still widely used by professional and recreational athletes who intend to quickly gain muscle mass and improve cardiovascular system performance. In the available

Table 2. Measurement of morphometric parameters and heart collagen content, mean \pm SD

\begin{tabular}{|c|c|c|c|c|}
\hline & Left ventricle tickness $\left(\boldsymbol{\mu M ^ { 2 } )}\right.$ & Longitudinal section diametar $(\boldsymbol{\mu M})$ & Cross-over area $\left(\boldsymbol{\mu M} \mathbf{M}^{2}\right.$ & Collagen content $(\%)$ \\
\hline $\mathrm{T}-\mathrm{N}-$ & $1704.306 \pm 180.309$ & $15 \pm 2.02$ & $152 \pm 17.074$ \\
\hline $\mathrm{T}-\mathrm{N}+$ & $1807.5 \pm 200.904$ & $16 \pm 1.87$ & $175 \pm 19.802$ & $0.8 \pm 0.201$ \\
\hline $\mathrm{T}+\mathrm{N}-$ & $2011.25 \pm 250.633$ & $19 \pm 3.27$ & $2.02 \pm 0.159$ & $0.39 \pm 0.203$ \\
\hline $\mathrm{T}+\mathrm{N}+$ & $2385 \pm 300.985$ & $20 \pm 2.66$ & $225 \pm 22.268$ & $0.53 \pm 0.194$ \\
\hline
\end{tabular}




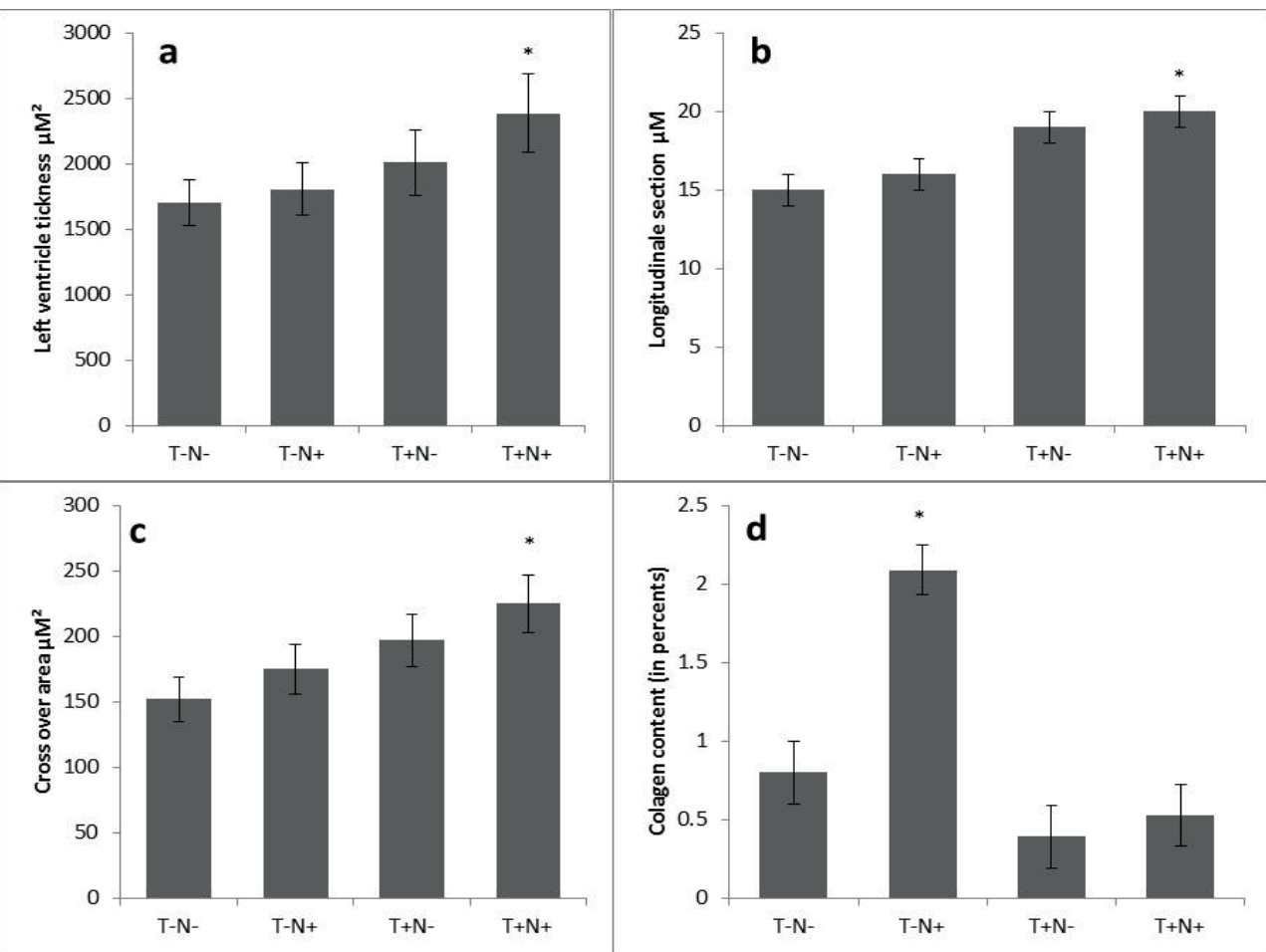

Figure 1. Values of left ventricle morphometric parameters after four weeks of study: a) Left ventricle thickness, b) Longitudinal section, c) Cross-sectional area, d) Collagen content. Each value is represented as the mean $\pm \mathrm{SD}$. (", $\mathrm{p}<0,05)$

literature, there is a plethora of information concerning the effects of chronic AAS abuse on the function and structure of numerous organs $(8,10,11,16)$. Similarly, researchers have shown that steroid abuse also induces changes in heart structure, ventricular thickness and size $(4,11,15,22,23)$, as well as heart connective tissue content $(5,15,17)$. Our results are in accordance with previous findings, as nandrolone, and especially nandrolone with training, induced significant increases of left ventricular thickness. We demonstrated that the effect of left ventricular hypertrophy occurring in animals exposed to nandrolone and training was $32 \%$ stronger than that in animals treated with nandrolone alone, and $40 \%$ stronger than in the control group. Furthermore researchers agree that steroids with or without training affect ventricular thickness in a dose-dependent manner, but in their studies, the most frequently investigated effects were the effects of supraphysiological doses of nandrolone (from 1-10 mg/kg per week) on the heart (24). However, due to dissimilarity of the administered doses of AAS, training processes and the durations of experimental treatments in various studies, it is difficult to draw a solid conclusion about the true effect of specific doses of steroids on heart tissue $(5,11,14,15,17)$. We demonstrated that high doses of steroids (up to $20 \mathrm{mg} /$ $\mathrm{kg}$ per week) as used in our study (many times higher than in some studies) caused thickening of the heart wall, but the degree of this change was not significantly higher than in earlier studies $(5,11,14,15,17)$. This means simply that the administration of steroids during training affects the heart in dose-dependent manner, but limits exists when doses of 20 $\mathrm{mg} / \mathrm{kg}$ or similar are reached. This is significant in our opinion because athletes who use steroids must be aware that higher doses of steroids or their derivatives will not improve the performance of cardiovascular system. Considering that the majority of the heart wall is composed of cardiac muscle cells, our findings related to the measurement of cell diameter confirm these findings. Unfortunately, we were unable to find sufficient data to compare the direct effects of various doses of steroids on cardiac myocyte size. A study published by Ren et al (2012) showed that steroids alone can induce cardiomyocyte hypertrophy (up to $35 \%$ at $100 \mathrm{nM}$ of dexamethasone) a dose much higher than that used in our study (15\% increase with nandrolone alone). The divergence may be the result of different study design (e.g., their study was performed in cell culture conditions); therefore, the doses of the hormones may not be comparable. Nevertheless, the increases in cardiomyocyte size observed in our experiment were consistent with the ventricular wall thickening also observed. This was particularly obvious when the cross-area of the heart muscle cells was measured.

Another adverse effect of nandrolone abuse is increased heart collagen content. Our results showed that the most significant collagen deposition between cardiac myocytes was observed in the animals that were treated with nandrolone alone. Furthermore, the lowest collagen content was observed in the hearts of the animals that were exposed to training alone or in animals exposed to both nandrolone and training. This proves that training is the most significant way to reduce the collagen-related adverse effects of steroids. These results coincide with the findings of previous studies (5) but are in conflict with the findings of Tano et al (2011), who stated that the collagen content is highest in hearts of animals that were exposed to combined nandrolone and training. On the other hand, our results are in accordance with those of Franquni et al (2013). They found that nandrolone alone, administered in the same dose as in our study but twice a week, caused a 
10-fold increase of heart collagen. The increase in heart collagen content observed in our study among animals exposed only to nandrolone was 2.5-fold compared to controls (261\% increase). These significant differences in results only show that further investigation is needed on the effects of AAS on heart collagen deposition. Nevertheless, our findings and those of Franquni et al lead us to the conclusion that dose-dependent heart collagen deposition is not limited, even at the highest doses. In contrast to the nandrolone effect, our study showed that training induces a decrease in collagen content of the heart. Similar findings were reported by other researchers (5), which demonstrates that exercise can minimize the adverse collagen deposition effect of steroids.

In general, our study demonstrates that nandrolone abuse has serious adverse effects on heart morphology. High doses of steroids, used by some misinformed athletes during the training process, induces significant collagen deposition and heart fibrosis, but does not significantly increase left ventricular thickness compared to lower supraphysiological doses.

\section{REFERENCES}

1. Angell P, Chester N, Green D, Somauroo J, Whyte G, George K. (2012) Anabolic steroids and cardiovascular risk. Review. Sports Med. 42(2):119-34.

2. Nieschlag E, Vorona E. (2015) Doping With AAS: adverse effectson non-reproductive organs and function. Rev Endocr Metab Disord. 16(3):199-211.

3. Piacentino D, Kotzalidis GD, Del Casale A, Aromatario MR, Pomara C, Girardi P ,Sani G. (2015) Anabolic-androgenic steroids use and psychopathology in athlets. A systematic review. Curr Neuropharmacol. 13(1):101-21.

4. De Piccoli B1, Giada F, Benettin A, Sartori F, Piccolo E. (1991) Anabolic steroid use in body builders: an echocardiographic study of left ventricle morphology and function. Int J Sports Med 12 (4):408-12.

5. Rocha FL, Carmo EC, Roque FR, Hashimoto NY, Rossini LV, Frimm C, Aneas I, Neagro CE, Krieger JE, Oliveira EM. (2007) Anabolic steroids induce cardiac reninangiotensin system and impair the beneficial effects of aerobic training in rats. Am J Physiol Heart Circulation Physiol, 293(6):H3575-83.

6. Yesalis CE, Bahrke MS. (1995) Anabolic-androgenic steroids. Current issues.Sports Med. 19(5):326-40

7. Shahidi NT. (2001) A review of the chemistry, biological action, and clinical applications of anabolic-androgenic steroids. Clin Ther. 23(9):1355-90.

8. Stephan Pinheiro Frankenfeld, Leonardo Pires de Oliveira, Daniele Leão Ignacio, Raquel Guimarães Coelho, Mariana Nigro Mattos, Andrea Claudia Freitas Ferreira, Denise Pires Carvalho and Rodrigo Soares Fortunato. (2014) Nandrolone decanoate inhibits gluconeogenesis and decreases fasting glucose in Wistar male rats. J Endocrinol. 220(2):143-53.
9. Payne JR, Kotwinski PJ, Montgomery HE. (2004) Cardiac effects of anabolic steroid. Heart. 90 (5): 473-5

10. Tylicki A, Kawalko A, Sokolska J, Strumilo S. (2007) Effect of anabolic steroid nandrolone deaconate on enzymes in the heart, liver and muscle of rats and rat's electrophysiology. Horm Metab Res. 39 (4):268-72

11. Frati P, Busardo FP, Cipolloni L, Dominicis ED, Fineschi V. (2015) Anabolic androgenic steroids ( AAS) related deaths: autoptic, histopathologycal and toxicologycal findings. Curr Neuropharmacol. 13(1):146-59

12. Fineschi V. (2013) Chronic, supra-physiological doses of nandrolone decanoate and exercise induced cardiotoxicity in an animal-model study. Acta Physiol (Oxf). 208(2):1413.

13. Phillis BD, Abeywardena MY, Adams MJ, Kennedy JA, Irvine RJ. (2007) Nandrolone potentiates arrhythmogenic effects of cardiac ischemia in the rat. Toxicol Sci 99(2):605- 11

14. Hassan AF1, Kamal MM. (2013) Effect of exercise training and anabolic androgenic steroids on hemodynamics, glycogen content, angiogenesis and apoptosis of cardiac muscle in adult male rats. Int J Health Sci (Qassim) 7(1):47-60.

15. Tanno AP, das Neves VJ, Rosa KT, Cunha TS, Giordano FC, Calil CM, Guzzoni V, Fenandes T, de Oliveira EM, Novaes PD, Irigoyen MC, Moura MJ, Marcondes FK. (2011) Nandrolone and resistance training induce heart remodeling: role of fetal genes and implications for cardiac pathophysiology. Life Sci 89(17-18):631-7.

16. Takahashi M, Tatsugi T, Kohno T. (2004) Endocrinological and pathological effects of anabolic-androgenic steroid in male rat. Endocr J. 51(4):425-34

17. Franquni JV, do Nascimento AM, de Lima EM, Brasil GA, Heringer OA, Cassaro KO, da Cunha TV, Musso C, Silva Santos MC, Kalil IC, Endringer DC, Boëchat GA, Bissoli NS, de Andrade TU. (2013) Nandrolone decanoate determines cardiac remodeling and injury by an imbalance in cardiac inflammatory cytokines and ACE activity, blunting of the Bezold-Jarisch reflex, resulting in the development of hypertension. Steroids. 78(3):379-85.

18. Fineschi V, Riezzo I, Centini F, Silingardi E, Licata M, Karch SB. ( 2005) Sudden cardiac death during anabolic steroid abuse: morphologic and toxicologic finding in two fatal cases of bodybuilders. Int J Legal Med. 15:1-6.

19. Pluim BM, Zwinderman AH, van der Laarse A, van der Wall EE. (2000) The athlete's heart. A meta-analysis of cardiac structure and function. Circulation. 25;101(3):336-44.

20. Ellison GM, Waring CD, Vicinanza C, Torella D. (2012) Physiological cardiac remodeling in response to endurance exercise training: cellular and molecular mechanisms. Heart. 98(1):5-10.

21. Cunha TS, Tanno AP, Costa Sampaio Moura MJ, Marcondes FK. (2005) Influence of high-intensity exercise training and anabolic androgenic steroid treatment on rat tissue glycogen content Life Sci. 77(9):1030-43. 
22. Urhausen A, Hölpes R, Kindermann W. (1989) Oneand two-dimensional echocardiography in bodybuilders using anabolic steroids. Eur J Appl Physiol Occup Physiol. 58(6):633-40.

23. Montisci M, El Mazloum R, Cecchetto G, Terranova C, Ferrara SD, Thiene G, Basso C. (2012) Anabolic androgenic steroids abuse and cardiac death in athletes: morphological and toxicological findings in four fatal cases. Forensic Sci Int. 217(1-3):e13-8.
24. Nikolic T, Zivkovic V, Jevdjevic M, Djuric M, Srejovic I, Djuric D, Jeremic N, Djuric D, Bolevich S, Jakovljevic V. (2015) The effets of chronic administration of nandrolone decanoate on redox status on exercised rats. Mol Cell Biochem. [Epub ahead of print].

25. Ren R, Oakley RH, Cruz-Topete D, Cidlowski JA. (2012) Dual role for glucocorticoids in cardiomyocyte hypertrophy and apoptosis. Endocrinology.153(11):5346-60. 